\title{
Reaksi Pasar Modal terhadap Kunjungan Raja Arab dan Presiden Korea Selatan ke Indonesia
}

\author{
Laila Cahyaning Palupi ${ }^{1}$ \\ Ardian Prima Putra ${ }^{2}$ \\ Sari Widati ${ }^{3}$ \\ Fakultas Ekonomi, Universitas Veteran Bangun Nusantara ${ }^{123}$ \\ ardian.putura@gmail.com ${ }^{2}$
}

\begin{abstract}
The purpose of this study is to analyze the capital market reaction to a political event. The event of visitation of the Arab King to Indonesia on Maret 1st-9th 2017 and visitation of the President of South Korea to Indonesia on November 9th 2017 on the members of stock index LQ45. The sampling method used in this study was purposive sampling with a total sample of 30. The data analysis technique used was Paired Sample Test with the event period of 11 days. The results of the analysis show the following: 1) Not difference in average abnormal return before and after visitation of the Arab King to Indonesia. 2) There are difference in average trading volume activity before and after visit of the Arab King in Indonesia. 3) Not difference in average abnormal return and average trading volume activity before and after visitation of the President of South Korea to Indonesia. 4) The visitation of the Arab King to Indonesia has increased compared to the visitation of the President of South Korea to Indonesia.
\end{abstract}

Keywords: event study; abnormal return; trading volume activity

\section{PENDAHULUAN}

Herawati dkk., (2017) menyatakan bahwa informasi merupakan hal yang penting bagi investor dan pelaku bisnis. Berdasar informasi tersebut investor dan pelaku bisnis akan mendapatkan gambaran mengenai keadaan pasar, baik di masa yang lalu maupun di masa yang akan datang. Salah satu informasi politik pada tahun 2017 yaitu kunjungan Raja Arab Salman bin Abdulaziz Al- Saud ke Indonesia pada Rabu 1 Maret 2017 dengan membawa 1.500 rombongan. Kunjungan tersebut begitu istimewa, sebab terakhir Raja Arab berkunjung ke Indonesia pada tahun 1970. Kunjungan Raja Arab ke Indonesia tidak hanya untuk menghadiri undangan Presiden Joko Widodo, tetapi kunjungan Raja Arab tersebut juga 
Journal of Business Finance and Economic (JBFE)

Volume 1, Nomor 1, Juni 2020

http://journal.univetbantara.ac.id/index.php/jbfe

membahas kerjasama antara Arab Saudi dengan Indonesia, serta Raja Arab juga berinvestasi di Indonesia sebesar USD 7 miliar (kompas.com, 1 Maret 2017).

Investasi tersebut merupakan langkah yang diambil Arab untuk mengurangi ketergantungan terhadap minyak dunia dan untuk menstabilkan perekonomian Arab, karena Arab adalah negara pengekspor minyak tertinggi di dunia dan perekonomiannya sangat tergantung pada minyak. Penurunan harga minyak sedikit saja sangatlah berpengaruh terhadap perekonomian Arab Saudi. Kunjungan kenegaraan yang lain adalah kunjungan Presiden Korea Selatan ke Indonesia pada tahun yang sama. Presiden Korea Selatan sangat menaruh perhatian pada Indonesia, dan melihat bahwa Indonesia memiliki prospek yang baik. Indonesia memiliki sumber daya alam terbesar di dunia yang membuat sejumlah perusahaan Korea Selatan sudah ataupun baru merencanakan investasi besar di Indonesia. Perusahaan Korea Selatan yang sudah bekerja sama dengan perusahaan Indonesia yaitu perusahaan raksasa baja Posko, yang memiliki usaha patungan bernilai miliaran dolar dengan Krakatau Steel Indonesia.

Putra (2016), menyatakan bahwa secara spesifik studi peristiwa adalah menyelidiki respon pasar terhadap kandungan informasi dari suatu pengumuman atau publikasi peristiwa tertentu. Reaksi pasar terhadap kandungan informasi tersebut, bisa berupa berita baik (good news) atau berita buruk (bad news). Reaksi pasar dapat diukur dengan return sebagai nilai perubahan harga atau dengan abnormal return. Penelitian yang menggunakan variabel abnormal return dan trading volume activity dilakukan oleh Hidayat dan Mukhlisin (2009) yang meneliti analisis pengumuman pembayaran deviden terhadap abnormal return saham pada perusahaan LQ 45 di Bursa Efek Indonesia, menghasilkan ada perbedaan abnormal return dan trading volume activity, sebelum dan sesudah pengumuman pembayaran deviden terhadap abnormal return saham pada perusahaan LQ 45 di Bursa Efek Indonesia. Penelitian Satria dan Supatmi (2013) yang membahas reaksi pasar sebelum dan sesudah internet financial reporting, menghasilkan ada perbedaan rata-rata abnormal return dan trading volume activity, sebelum dan sesudah internet financial reporting (IFR). Penelitian yang lainnya yaitu penelitian Jayanti dan Jayanti (2011) mengenai dampak kebangkrutan penerbangan: suatu peristiwa, menghasilkan bahwa abnormal return berpengaruh positif terhadap karir 
Journal of Business Finance and Economic (JBFE)

Volume 1, Nomor 1, Juni 2020

http://journal.univetbantara.ac.id/index.php/jbfe

pesaing sebagai akibat utama dari kebangkrutan tersebut.

Penelitian ini menggunakan periode pengamatan kunjungan Raja Arab dan kunjungan Presiden Korea ke Indonesia selama 11 hari yaitu 5 hari sebelum,1 hari saat kunjumgan, dan 5 hari setelah kunjungan tersebut. Penelitian ini mengambil sampel perusahaan LQ45. Liogu dan Saerang (2015) mengungkapkan bahwa sahamsaham yang terdaftar saham LQ45 adalah saham-saham yang aktif, sehingga saham-saham tersebut lebih sensitif untuk mendeteksi reaksi pasar terhadap suatu informasi, baik informasi keuangan atau informasi non-keuangan, serta saham LQ45 mewakili semua sektor saham yang ada di Bursa Efek Indonesia (BEI). Penelitian ini sangat menarik untuk diteliti, karena penelitian ini menggunakan dua event study. Setiap event study tidak hanya berpengaruh terhadap kinerja perusahaan saja, tetapi juga bepengaruh terhadap pasar modal, yang diantaranya berupa average abnormal return dan trading volume activity.

\section{KAJIAN PUSTAKA DAN PERUMUSAN HIPOTESIS}

\section{Event Study}

Putra (2016) menyatakan bahwa secara spesifik studi peristiwa menyelidiki respons pasar terhadap kandungan informasi dari suatu pengumuman atau publikasi peristiwa tertentu. Kandungan informasi tersebut bisa berupa berita baik (good news) atau berita buruk (bad news).

\section{Abnormal Return}

Hidayat dan Mukhlisin (2009) menyatakan bahwa abnormal return atau keuntungan di atas normal adalah selisih antara tingkat keuntungan sebenarnya dengan tingkat keuntungan yang diharapkan (return ekspektasi).

\section{Trading Volume Activity}

Herawati dkk., (2017), trading volume activity merupakan suatu alat instrumen yang dapat digunakan untuk melihat reaksi pasar modal terhadap informasi dan memberikan informasi apakah banyak saham yang dijual atau saham yang dibeli.

\section{Pengembangan Hipotesis}


Journal of Business Finance and Economic (JBFE)

Volume 1, Nomor 1, Juni 2020

http://journal.univetbantara.ac.id/index.php/jbfe

\section{Hubungan antara kunjungan Raja Arab di Indonesia dengan averageabnormal return (AAR).}

Penelitian sebelumnya dilakukan oleh Liogu dan Saerang (2015), menghasilkan bahwa ada perbedaan abnormal return, dan trading volume activity, sebelum dan sesudah pengumuman kenaikan harga bahan bakar minyak (BBM) atas saham LQ45 pada tanggal 1 November 2014 yang signifikan. Penelitian Hidayat dkk., (2016) menunjukkan adanya perbedaan yang signifikan rata-rata abnormal return dan trading volume activity (TVA) pada periode sebelum dan sesudah pengumuman penurunan BBM. Penelitian Hasib dkk., (2017), menunjukkan adanya perbedaan yang siginifikan abnormal return dan abnormal trading volume activity, pada periode sebelum dan sesudah perombakan kabinet kerja. Berdasarkan hasil penelitian-penelitian terdahulu, maka rumusan hipotesis pertama dalam penelitian ini adalah:

$\mathrm{H}_{1}$ : Terdapat perbedaan average abnormal return (AAR) 5 hari sebelum dan 5 hari sesudah peristiwa kunjungan Raja Arab ke Indonesia.

2. Hubungan antara kunjungan Raja Arab dengan average trading volume activity (ATVA).

Penelitian sebelumnya dilakukan oleh Herawati dkk., (2017) menghasilkan bahwa terdapat perbedaan rata-rata trading volume activity yang signifikan sebelum dan sesudah peristiwa pilihan presiden (pilpres) Amerika Serikat 2016. Penelitian Meidawati dan Harimawan (2004), menunjukkan adanya perbedaan nilai rata-rata volume perdagangan saham, pada periode sebelum dan sesudah peristiwa Pemilu Legislatif Indonesia tahun 2004. Penelitian Hasib dkk., (2017) menunjukkan adanya perbedaan yang siginifikan abnormal return dan abnormal trading volume activity, pada periode sebelum dan sesudah perombakan kabinet kerja. Berdasarkan hasil penelitian-penelitian terdahulu, maka rumusan hipotesis kedua dalam penelitian ini adalah:

$\mathrm{H}_{2}$ : Terdapat perbedaan average trading volume activity (ATVA) saham dalam 5 hari sebelum dan 5 hari sesudah peristiwa kunjungan Raja Arab Saudi ke Indonesia.

\section{Hubungan antara kunjungan Presiden Korea Selatan di Indonesia dengan} average abnormal return (AAR) 
Journal of Business Finance and Economic (JBFE)

Volume 1, Nomor 1, Juni 2020

http://journal.univetbantara.ac.id/index.php/jbfe

Penelitian sebelumnya dilakukan oleh Liogu dan Saerang (2015), menghasilkan bahwa terdapat perbedaan abnormal return dan trading volume activity, sebelum dan sesudah pengumuman kenaikan harga BBM atas saham LQ 45 pada tanggal 1 November 2014 secara signifikan. Penelitian Hidayat dkk., (2016) menunjukkan adanya perbedaan yang signifikan rata-rata abnormal return dan trading volume activity (TVA), pada periode sebelum dan sesudah pengumuman penurunan BBM. Penelitian Hasib dkk., (2017) menunjukkan adanya perbedaan yang siginifikan antara abnormal return dan abnormal trading volume activity, pada periode sebelum dan sesudah perombakan kabinet kerja. Berdasarkan hasil penelitian-penelitian terdahulu, maka rumusan hipotesis ketiga dalam penelitian ini adalah:

$\mathrm{H}_{3}$ : Terdapat perbedaan average abnormal return (AAR) dalam 5 hari sebelum dan 5 hari sesudah peristiwa kunjungan Presiden Korea Selatan ke Indonesia.

\section{Hubungan antara kunjungan Presiden Korea Selatan dengan average trading} volume activity (ATVA)

Penelitian sebelumnya dilakukan oleh Herawati dkk., (2017) menghasilkan bahwa terdapat perbedaan rata-rata trading volume activity yang signifikan pada sebelum dan sesudah peristiwa pilpres Amerika Serikat 2016. Penelitian Meidawati dan Harimawan (2004), menunjukkan adanya perbedaan nilai ratarata volume perdagangan saham pada periode sebelum dan sesudah peristiwa Pemilu Legislatif Indonesia tahun 2004. Penelitian Hasib dkk., (2017), menunjukkan adanya perbedaan yang signifikan abnormal return dan abnormal trading volume activity, pada periode sebelum dan sesudah perombakan kabinet kerja. Berdasarkan hasil penelitian-penelitian terdahulu, maka rumusan hipotesis yang keempat adalah:

$\mathrm{H}_{4}$ :Terdapat perbedaan average trading volume activity (ATVA) saham dalam 5 hari sebelum dan 5 hari sesudah peristiwa kunjungan Presiden Korea Selatan ke Indonesia.

\section{Hubungan Kunjungan Raja Arab dan Kunjungan Presiden Korea Selatan} dengan average trading volume activity (ATVA)

Penelitian Meidawati dan Harimawan (2004), menunjukkan kenaikan rata-rata 
Journal of Business Finance and Economic (JBFE)

Volume 1, Nomor 1, Juni 2020

http://journal.univetbantara.ac.id/index.php/jbfe

volume perdagangan saham pada sesudah peristiwa pemilu legislatif Indonesia tahun 2004. Penelitian Herawati dkk., (2017) menunjukkan bahwa terjadi kenaikan rata-rata volume perdagangan saham pada sesudah peristiwa pilpres Amerika Serikat 2016. Berdasarkan hasil penelitian-penelitian terdahulu, maka rumusan hipotesis kelima adalah:

$\mathrm{H}_{5}$ :Kunjungan Raja Arab atau Kunjungan Presiden Korea Selatan ke Indonesia yang mengalami peningkatan average trading volume activity (ATVA)

\section{METODE PENELITIAN}

\section{Sampel}

Populasi dalam penelitian ini adalah semua perusahaan LQ 45 yang terdaftar di Bursa Efek Indonesia. Penelitian ini menggunakan teknik pengambilan sampel purposive sampling, dengan kriteria yaitu sampel merupakan perusahaan-perusahaan LQ-45 dan listing di BEI pada periode 2017, perusahaan LQ 45 yang sahamnya memiliki harga saham yang baik atau bagus, perusahaan LQ 45 yang sama antara kunjungan Raja Arab dan kunjungan Presiden Korea Selatan ke Indonesia. Perusahaan LQ 45 yang memenuhi kriteria terdapat 30 perusahaan.

\section{Definisi Operasional dan Pengukuran Variabel}

\section{Menghitung average abnormal return dengan langkah-langkah sebagai}

\section{berikut:}

a. Return saham

Menurut Saputra dan Darsono (2015), actual return adalah return yang terjadi pada waktu ke-t, yang merupakan selisih dari harga sekarang relatif, terhadap harga sebelumnya t-1. Return saham dihitung dengan menggunakan rumusan:

Keterangan:

$$
\mathrm{R}_{\mathrm{it}}=\frac{\mathrm{P}_{\mathrm{it}}-\mathrm{P}_{\mathrm{it}-1}}{\mathrm{P}_{\mathrm{it}-1}}
$$

$\mathrm{R}_{\mathrm{it}} \quad=$ return sesungguhnya saham $\mathrm{i}$ hari

ke-t $\mathrm{P}_{\mathrm{it}}=$ harga penutupan saham i hari ke-t 
Journal of Business Finance and Economic (JBFE)

Volume 1, Nomor 1, Juni 2020

http://journal.univetbantara.ac.id/index.php/jbfe

Pit-t = harga penutupan saham i hari ke $\mathrm{t}-1$

b. Expected Return

Dalam penelitian ini, perhitungan return ekspektasi (expected return) menggunakan model estimasi, yaitu model disesuaikan pasar (market adjusted model).

$$
E\left(R_{i, t}\right)=\frac{L Q 45_{t}-L Q 45_{t-1}}{L Q 45_{t-1}}
$$

Keterangan:

$\mathrm{E}\left[\mathrm{R}_{\mathrm{i}, \mathrm{t}}\right]=\mathrm{M}_{\mathrm{it}}$

$\mathrm{R}_{\mathrm{i}, \mathrm{t}} \quad=$ return pasar periode $\mathrm{t}$

LQ 45t $=$ indeks LQ 45 harian untuk periode $t$ LQ

$45_{\mathrm{t}-1}=$ indeks LQ 45 harian untuk periode $\mathrm{t}-1$

c. Abnormal Return

Mulatsih, Maskie, dan Susanto (2009) menyatakan bahwa abnormal return adalah kelebihan return yang sesungguhnya terjadi, terhadap return normal (return ekspektasi). Rumus perhitungan abnormal return dengan market adjusted model adalah:

$$
\mathrm{AR}_{\mathrm{it}}=\mathrm{R}_{\mathrm{it}}-E\left(\mathrm{R}_{\mathrm{it}}\right)
$$

Keterangan :

$\mathrm{AR}_{\mathrm{it}} \quad=$ return tidak normal saham i pada hari ke-t

$\mathrm{R}_{\mathrm{it}} \quad=$ return sesungguhnya untuk saham i pada hari ke-t

$E\left(\mathrm{R}_{\mathrm{it}}\right) \quad=$ return ekspektasian untuk saham i pada hari ke-t

d. Rata-Rata Abnormal Return

Saputra dan Darsono (2015) menyatakan bahwa rata-rata abnormal return (AAR) sebelum dan sesudah peristiwa pengumuman, menggunakan rumus:

$$
\mathrm{AAR}_{\mathrm{t}}=\frac{\mathrm{AR}_{\mathrm{t}}}{\mathrm{n}}
$$

Keterangan: 
Journal of Business Finance and Economic (JBFE)

Volume 1, Nomor 1, Juni 2020

http://journal.univetbantara.ac.id/index.php/jbfe

$$
\begin{array}{ll}
\text { AARt } & =\text { rata-rata abnormal return pada periode ke-t } \\
\text { ARt } & =\text { abnormal return saham pada periode peristiwa } \\
\text { ke-t } \mathrm{n} & =\text { jumlah sampel/jumlah emiten yang diamati }
\end{array}
$$

\section{Rumus mencari average trading volume activity (ATVA)}

Meidawati dan Harimawan (2004) menyatakan bahwa Volume perdagangan saham diukur dengan melihat indikator aktivitas volume perdagangan, selanjutnya disebut trading volume activity (TVA). Rumus TVA yaitu:

Menghitung rata-rata volume perdagangan untuk semua saham yang dijadikan sampel dengan rumus sebagai berikut:

$$
\text { ATVA } \frac{\sum \text { TV }}{n}
$$

Keterangan:

$\overline{\mathrm{ATVA}}=$ rata-rata trading volume activity (TVA)

TVA = trading volume activity

$\mathrm{n} \quad=$ Jumlah Perusahaan

\section{HASIL DAN PEMBAHASAN}

\section{Uji Normalitas}

Saputra dan Darsono (2015) menyatakan bahwa uji normalitas digunakan untuk mengetahui apakah data tersebar secara normal atau tidak. Sebelum melakukan uji statistik, langkah awal yang harus dilakukan adalah screening terhadap data yang akan diolah. Dalam penelitian ini pengujian hipotesis dilakukan dengan menggunakan uji beda (T-test) untuk sampel yang berhubungan (paired samples t-test). Asumsi yang digunakan untuk penggunaan alat statistik tersebut yaitu data harus terdistribusi secara normal. Untuk mendeteksi normalitas data average abnormal return (AAR), average trading volume activity (ATVA) sebelum dan sesudah pengumuman dividen tunai, digunakan uji one-sample kolomogrov smirnov test. Langkah awal yang harus dilakukan adalah dengan menentukan terlebih dahulu hipotesis pengujian, yaitu:

- Ho : data terdistribusi secara normal

- Ha : data tidak terdistribusi secara normal 
Journal of Business Finance and Economic (JBFE)

Volume 1, Nomor 1, Juni 2020

http://journal.univetbantara.ac.id/index.php/jbfe

Jika hasil pengolahan data one-sample kolomogrov smirnov test menghasilkan probabilitas signifikansi dibawah $5 \%(0,05)$, berarti $\mathrm{H}_{0}$ ditolak atau data variabel tersebut tidak terdistribusi secara normal.

Tabel 1.

One-Sample Kolmogorov-Smirnov Test

\begin{tabular}{|c|c|c|c|c|c|}
\hline & & $\begin{array}{c}\text { AAR } \\
\text { SEBELUM } \\
\text { ARAB } \\
\end{array}$ & $\begin{array}{c}\text { AAR } \\
\text { SESUDAH } \\
\text { ARAB } \\
\end{array}$ & $\begin{array}{c}\text { ATVA } \\
\text { SEBELUM } \\
\text { ARAB }\end{array}$ & $\begin{array}{c}\text { ATVA } \\
\text { SESUDAH } \\
\text { ARAB }\end{array}$ \\
\hline \multirow[t]{2}{*}{$\mathrm{N}$} & & 5 & 5 & 5 & 5 \\
\hline & Mean & $-0,0016$ & $-0,0006$ & 0,0034 & 0,0051 \\
\hline \multirow{2}{*}{ Normal Parameters ${ }^{\mathrm{a}, \mathrm{b}}$} & Std. & 0,0065 & 0,0075 & 0,0004 & 0,0012 \\
\hline & Absolute & 0,1450 & 0,1970 & 0,2370 & 0,3170 \\
\hline \multirow[t]{2}{*}{ Most Extreme Differences } & Positive & 0,1420 & 0,1970 & 0,2370 & 0,1760 \\
\hline & Negative & $-0,1450$ & $-0,1540$ & $-0,1620$ & $-0,3170$ \\
\hline \multicolumn{2}{|c|}{ Kolmogorov-Smirnov Z Asymp. } & 0,3240 & 0,4400 & 0,5300 & 0,7100 \\
\hline \multicolumn{2}{|c|}{ Sig. (2-tailed) } & 1,0000 & 0.9900 & 0,9420 & 0,6950 \\
\hline
\end{tabular}

Sumber:data telah diolah

Berdasarkan tabel 1 uji one sample kolmogorov-smirnov dari variabel average abnormal return (AAR) dan average trading volume activity (ATVA), sebelum dan sesudah kunjungan Raja Arab ke Indonesia terdistribusi normal (Ho diterima).

Tabel 2.

One-Sample Kolmogorov-Smirnov Test

\begin{tabular}{lcccc}
\hline & \multicolumn{3}{c}{} \\
\cline { 2 - 5 } & $\begin{array}{c}\text { AAR } \\
\text { SEBELUM } \\
\text { KORSEL }\end{array}$ & $\begin{array}{c}\text { AAR } \\
\text { SESUDAH } \\
\text { KORSEL }\end{array}$ & $\begin{array}{c}\text { ATVA } \\
\text { SEBELUM } \\
\text { KORSEL }\end{array}$ & $\begin{array}{c}\text { ATVA } \\
\text { SESUDAH } \\
\text { KORSEL }\end{array}$ \\
\hline $\mathrm{N}$ & 5 & 5 & 5 & 5 \\
Normal Parameters & $-0,0021$ & $-0,0045$ & 0,0024 & 0,0020 \\
a,b Mean & 0,0034 & 0,0156 & 0,0004 & 0,0005 \\
Std. Deviation & 0,1850 & 0,3240 & 0,4210 & 0,2790 \\
Most Extreme Differences & 0,1850 & 0,1870 & 0,2820 & $.0,2790$ \\
Kolmogorov-Smirnov Z Asymp. & $-0,1540$ & $-0,3240$ & $-0,4210$ & $-0,2200$ \\
Sig. (2-tailed) & 0,4140 & 0,7250 & 0,9420 & 0,6240 \\
\hline
\end{tabular}

Sumber: data telah diolah

Berdasarkan tabel 2, uji one sample kolmogorov-smirnov dari variabel average abnormal return (AAR) dan average trading volume activity (ATVA) sebelum dan sesudah kunjungan Presiden Korea Selatan ke Indonesia terdistribusi normal (Ho diterima).

\section{Uji Paired Sample Test}

Pengujian hipotesis menggunakan uji t untuk observasi yang berpasangan 
Journal of Business Finance and Economic (JBFE)

Volume 1, Nomor 1, Juni 2020

http://journal.univetbantara.ac.id/index.php/jbfe

(paired sample t test). Pengambilan keputusan menggunakan tingkat kepercayaan 95\% atau $\alpha=5 \%$ dengan ketentuan sebagai berikut :

- Jika tingkat signifikansi < 0,0500, maka Ha diterima dan Ho ditolak.

- Jika tingkat signifikansi > 0,0500, maka Ha ditolak dan Ho diterima.

\section{a. Hipotesis Pertama}

Hipotesis pertama dalam penelitian ini adalah terdapat perbedaan average abnormal return (AAR) antara 5 hari sebelum dan 5 hari sesudah kunjungan Raja Arab ke Indonesia diperoleh hasil sebagai berikut:

Tabel 3.

\begin{tabular}{ccccc}
\multicolumn{6}{c}{ AAR Sebelum dan AAR Sesudah Kunjugan Raja Arab ke Indonesia } \\
\hline $\begin{array}{c}\text { RATA-RATA } \\
\text { AAR SEBELUM } \\
\text { ARAB }\end{array}$ & $\begin{array}{c}\text { RATA-RATA } \\
\text { AAR SESUDAH } \\
\text { ARAB }\end{array}$ & PERBEDAAN & NILAIT & $\begin{array}{c}\text { SIG. (2- } \\
\text { AITUILE }\end{array}$ \\
\hline$-0,0016$ & $-0,0006$ & 0,0010 & $-0,3180$ & 0,7660 \\
\hline
\end{tabular}

Sumber: data telah diolah

Pengujian hipotesis pertama menunjukan bahwa average abnormal return (AAR) mengalami kenaikan 0,0010, sesudah kunjungan Raja Arab ke Indonesia tetapi tidak terdapat perbedaan AAR, selama lima hari sebelum dan lima hari sesudah kunjungan Raja Arab ke Indonesia. Hal ini dibuktikan dengan hasil pengujian paired sample test, yang menunjukan bahwa tingkat signifikansi hasil pengujian sebesar $\alpha=0,7660>0,05$. Tidak adanya perbedaan AAR yang signifikan dalam peristiwa kunjungan Raja Arab ke Indonesia menunjukkan bahwa informasi yang terkandung dalam peristiwa tersebut tidak besar dan kuat, sehingga secara signifikan tidak terlihat perbedaan AAR, meskipun pasar bereaksi atas peristiwa tersebut yang ditunjukkan dengan terjadinya perubahan harga saham dari kondisi sebelum ke sesudah. Namun, reaksi tersebut tidak cukup kuat untuk membuat adanya perbedaan AAR, sebelum dan sesudah kunjungan Raja Arab ke Indonesia. Hasil penelitian ini memiliki kesamaan dengan hasil penelitian yang dilakukan oleh Herawati dkk. (2017), yang mengemukakan bahwa tidak terdapat perbedaan average abnormal return (AAR) yang signifikan, sebelum dan sesudah peristiwa pilpres Amerika Serikat 2016.

\section{b. Hipotesis Kedua}


Hipotesis kedua dalam penelitian ini adalah terdapat perbedaan average trading volume activity (ATVA), dalam 5 hari sebelum dan 5 hari sesudah kunjungan Raja Arab ke Indonesia, diperoleh hasil sebagai berikut:

Tabel 4.

ATVA Sebelum dan ATVA Sesudah Kunjugan Raja Arab ke Indonesia

\begin{tabular}{ccccc}
\hline $\begin{array}{c}\text { RATA-RATA ATVA } \\
\text { SEBELUM ARAB }\end{array}$ & $\begin{array}{c}\text { RATA-RATA ATVA } \\
\text { SESUDAH ARAB }\end{array}$ & PERBEDAAN & NILAI T & SIG. (2- \\
& HITUNG & TAILED) \\
0,0034 & 0,0051 & 0,0017 & $-3,7920$ & 0,0190 \\
\hline
\end{tabular}

Sumber: data telah diolah

Pengujian hipotesis kedua menunjukan bahwa average trading volume activity (ATVA) mengalami kenaikan 0,0017, sesudah kunjungan Raja Arab ke Indonesia, serta terdapat perbedaan ATVA lima hari sebelum dan lima hari sesudah kunjungan Raja Arab ke Indonesia. Hal ini dibuktikan dengan hasil pengujian paired sample test, yang menunjukkan bahwa tingkat signifikansi hasil pengujian sebesar 0,0190 <0,0500. Hasil analisis ini menunjukkan, kemungkinan adanya kandungan informasi kunjungan Raja Arab ke Indonesia yang mempengaruhi preferensi investor dalam pembuatan keputusan investasi, sehingga pasar bereaksi atas informasi tersebut. Reaksi pasar ini hanya dapat mengubah harga saham dan membuat ATVA mengalami peningkatan sebesar 0,0017, sesudah kunjungan Raja Arab ke Indonesia, tetapi tidak mengubah abnormal return. Hasil penelitian ini memiliki kesamaan dengan hasil penelitian yang dilakukan oleh Meidawati dan Harimawan (2004), yang menghasilkan bahwa terdapat perbedaan ATVA pada periode sebelum dan sesudah peristiwa Pemilu Legislatif Indonesia tahun 2004.

\section{c. Hipotesis ketiga}

Hipotesis ketiga dalam penelitian ini adalah terdapat perbedaan average abnormal return (AAR), dalam 5 hari sebelum dan 5 hari sesudah kunjungan Presiden Korea Selatan ke Indonesia, diperoleh hasil sebagai berikut:

Tabel 5.

AAR Sebelum dan AAR Sesudah Kunjugan Presiden Korea Selatan ke Indonesia

\begin{tabular}{ccccc}
\hline $\begin{array}{c}\text { RATA-RATA AAR } \\
\text { SEBELUM KOREA }\end{array}$ & $\begin{array}{c}\text { RATA-RATA AAR } \\
\text { SESUDAH KOREA }\end{array}$ & PERBEDAAN & $\begin{array}{c}\text { NILAI T } \\
\text { HITUNG }\end{array}$ & $\begin{array}{c}\text { SIG. (2- } \\
\text { TAILED) }\end{array}$ \\
\hline$-0,0021$ & $-0,0045$ & $-0,0024$ & 0,3570 & 0,7390 \\
\hline
\end{tabular}

Sumber :data telah diolah

Pengujian hipotesis ketiga menunjukan bahwa average abnormal return (AAR) mengalami penurunan 0,0024, sesudah kunjungan Presiden 
Journal of Business Finance and Economic (JBFE)

Volume 1, Nomor 1, Juni 2020

http://journal.univetbantara.ac.id/index.php/jbfe

Korea Selatan ke Indonesia, tetapi tidak terdapat perbedaan AAR dalam lima hari sebelum dan lima hari sesudah kunjungan Presiden Korea Selatan ke Indonesia. Hal ini dibuktikan dengan hasil pengujian paired sample test, yang menunjukkan bahwa tingkat signifikansi hasil pengujian sebesar 0,7390 > 0,0500. Pasar modal secara umum bereaksi biasa saja terhadap kunjungan Presiden Korea Selatan ke Indonesia. Reaksi pasar yang diukur dengan AAR sebelum dan sesudah kunjungan tersebut tidak mengalami perbedaan yang signifikan. Reaksi pasar secara keseluruhan normal seperti biasanya, karena kunjungan Presiden Korea Selatan ke Indonesia sudah diketahui sebelumnya. Hasil penelitian ini memiliki kesamaan dengan hasil penelitian yang dilakukan oleh Herawati dkk. (2017), menghasilkan tidak terdapat perbedaan AAR yang signifikan sebelum dan sesudah peristiwa pilpres Amerika Serikat 2016.

\section{d. Hipotesis Keempat}

Hipotesis keempat dalam penelitian ini adalah terdapat perbedaan average trading volume activity (ATVA), dalam 5 hari sebelum dan 5 hari sesudah kunjungan Presiden Korea Selatan ke Indonesia. diperoleh hasil sebagai berikut:

Tabel 6.

ATVA Sebelum dan ATVA Sesudah Kunjungan Presiden Korea Selatan ke Indonesia

\begin{tabular}{ccccc}
\hline RATA-RATA & RATA-RATA \\
$\begin{array}{c}\text { ATVA SEBELUM } \\
\text { KOREA }\end{array}$ & $\begin{array}{c}\text { ATVA SESUDAH } \\
\text { KOREA }\end{array}$ & & NILAI T & SIG. (2- \\
\hline 0,0024 & 0,0020 & $-0,0004$ & 1,9630 & 0,1210 \\
\hline
\end{tabular}

Sumber :data telah diolah

Pengujian hipotesis keempat menunjukan bahwa average trading volume activity (ATVA) mengalami penurunan 0,0004, sesudah kunjungan Presiden Korea Selatan ke Indonesia, tetapi tidak terdapat perbedaan ATVA dalam 5 hari sebelum dan 5 hari sesudah kunjungan Presiden Korea Selatan ke Indonesia. Hal ini dibuktikan dengan hasil pengujian paired sample test, yang menunjukkan bahwa tingkat signifikansi hasil pengujian sebesar 0,1210> 0,0500. Reaksi pasar terhadap kunjungan Presiden Korea Selatan ke Indonesia, tidak membuat para investor terburu-buru dalam mengambil 
Journal of Business Finance and Economic (JBFE)

Volume 1, Nomor 1, Juni 2020

http://journal.univetbantara.ac.id/index.php/jbfe

keputusan menjual maupun membeli saham. Investor menganggap bahwa kunjungan tersebut hanya mengubah harga saham dalam waktu dekat saja. Pasar juga sudah telah terlebih dahulu mengetahui dan mengantisipasi peristiwa tersebut. Hasil penelitian ini memiliki kesamaan dengan hasil penelitian yang dilakukan oleh Luhur (2010), yang menunjukkan bahwa tidak ada perbedaan rata-rata aktivitas volume perdagangan secara signifikan, sebelum dan sesudah peristiwa pemilu presiden dan wakil presiden 8 Juli 2009 pada saham LQ-45 yang terdaftar di BEI.

\section{e. Hipotesis Kelima}

Hipotesis kelima dalam penelitian ini adalah kunjungan Raja Arab atau kunjungan Presiden Korea Selatan ke Indonesia yang mengalami peningkatan average trading volune activity (ATVA) diperoleh hasil sebagai berikut:

\section{Tabel 7.}

ATVA Kunjungan Raja Arab dan ATVA Kunjungan

Presiden Korea Selatan ke Indonesia

\begin{tabular}{lcc}
\hline & Mean & Std. Deviation \\
\hline ATVA SEBELUM ARAB & 0,0034 & 0,0004 \\
ATVA SESUDAH ARAB & 0,0051 & 0,0012 \\
ATVA SEBELUM KORSEL & 0,0024 & 0,0004 \\
ATVA SESUDAH KORSEL & 0,0020 & 0,0005 \\
\hline
\end{tabular}

Berdasarkan tabel 7 dapat dilihat bahwa mean ATVA, sebelum kunjungan Raja Arab ke Indonesia bernilai positif sebesar 0,0034 dengan standar deviasi 0,0004, mean ATVA sesudah kunjungan Raja Arab ke Indonesia sebesar 0.0051 dengan standar deviasi 0,0012. Berarti mean ATVA sesudah kunjungan Raja Arab ke Indonesia, mengalami peningkatan sebesar 0,0017. Nilai mean ATVA sebelum kunjungan Presiden Korea Selatan ke Indonesia bernilai positif sebesar 0,0024, dengan standar deviasi 0,0004 dan mean ATVA sesudah kunjungan Presiden Korea Selatan ke Indonesia sebesar 0.0020 dengan standar deviasi 0,0005. Berarti mean ATVA sesudah kunjungan Presiden Korea Selatan ke Indonesia, mengalami penurunan sebesar 0,0004. Berarti ATVA kunjungan Raja Arab ke Indonesia mengalami peningkatan sesudah kunjungan tersebut, dibandingkan ATVA kunjungan Presiden Korea Selatan ke Indonesia yang mengalami penurunan sesudah kunjungan tersebut.

\section{KESIMPULAN DAN SARAN}


Journal of Business Finance and Economic (JBFE)

Volume 1, Nomor 1, Juni 2020

http://journal.univetbantara.ac.id/index.php/jbfe

1. Hasil dari pengujian tersebut menunjukan bahwa average abnormal return mengalami kenaikan sesudah kunjungan Raja Arab ke Indonesia, tetapi tidak terdapat perbedaan average abnormal return dalam 5 hari sebelum dan 5 hari sesudah kunjungan Raja Arab ke Indonesia. Average trading volume activity mengalami kenaikan sesudah kunjungan Raja Arab ke Indonesia serta terdapat perbedaan average trading volume activity, dalam 5 hari sebelum dan 5 hari sesudah kunjungan Raja Arab ke Indonesia. Kunjungan Raja Arab ke Indonesia dapat meningkatkan average trading volume activity.

2. Hasil dari pengujian tersebut menunjukan bahwa average abnormal return dan average trading volume activity mengalami penurunan sesudah kunjungan Presiden Korea Selatan ke Indonesia, tetapi tidak menimbulkan perbedaan average abnormal return dan average trading volume activity dalam 5 hari sebelum dan 5 hari sesudah kunjungan Presiden Korea Selatan ke Indonesia. Kunjungan Presiden Korea Selatan ke Indonesia mengakibatkan penurunan average trading volume activity.

3. Bagi Penelitian Selanjutnya

Bagi peneliti di masa mendatang seharusnya tidak hanya terpaku menggunakan perusahaan LQ45 saja, tetapi bisa menggunakan perusahaanperusahaan yang lebih luas lagi, misalnya perusahaan manufaktur, juga bisa perusahaan Indeks Harga Saham Gabungan (IHSG), penggunaan periode pengamatan perlu lebih lama untuk melihat reaksi pasar yang lebih nyata dan hasil yang lebih akurat lagi, tidak hanya menggunakan dua variabel saja, peneliti bisa menggunakan lebih dari dua variabel dalam penelitian selanjutnya di masa mendatang.

4. Bagi Pemerintah dan Investor

Pemerintah harus memahami sensitivitas dari para investor, dengan selalu menciptakan stabilitas politik, keamanan, dan ekonomi, agar pasar modal Indonesia tetap bergairah. Bagi Investor, disarankan agar lebih berhati-hati dalam mengambil keputusan yang tepat dan benar, supaya keputusan investor tersebut tidak merugikan investor sendiri. Investor perlu mempertimbangkan kandungan informasi yang tersedia, apakah informasi tersebut merupakan berita yang baik atau buruk, agar dapat memperoleh keuntungan yang besar pada investasi.

\section{DAFTAR PUSTAKA}


Chandra, Chan Hengky. Anastasia, Njo dan Memarista, Gesti. 2014. Perbedaan average abnormal return, average trading volume activity sebelum dan sesudah pemilu di Indonesia. FINESTA. Vol. 2. No. 1

Choriliyah, Siti; Sutanto, Himawan Arif dan Hidayat, Dwi Suryanto. 2016. Reaksi Pasar Modal terhadap Penurunan Harga Bahan Bakar Minyak (BBM) atas Saham Sektor Industri Transportasi di Bursa Efek Indonesia. Journal of Economic Education. Vol. 5. No. 1. P-ISSN 2301-7341 / E-ISSN 2502-4485

Hasib, Fatin Fadhilah dkk. 2017.The Effect of The Working Cabinet Reshuffle Volume II on Abnormal Return and Abnormal Trading Volume Activity of The Companies Listed in Jakarta Islamic Index (JII). Advances in Economics, Business and Management Research. Vol. 36

Hidayat, Riskin dan Mukhlisin, Muhammad. 2009. Analisis Pengumuman Pembayaran Deviden terhadap Abnormal Return Saham pada Perusahaan LQ 45 di Bursa Efek Indonesia. POTENSIO. Vol. 10. No. 2. ISSN 1829-7978

Jayanti, Rama K. dan Jayanti, S.V. 2011. Effects Of Airline Bankruptcies: An Event study. Journal of Services Marketing. Vol. 25. Iss 6. pp. 399 409

Liogu, Stesia Juliana dan Saerang, Ivonne S.2015.Reaksi Pasar Modal terhadap Pengumuman Kenaikan Harga BBM atas Saham LQ 45 pada tanggal 1 November 2014. Jurnal EMBA. Vol.3. No.1. ISSN 2303-1174

Luhur, Suryo. 2010. Reaksi Pasar Modal Indonesia seputarPemilihanUmum 8 Juli 2009 pada Saham LQ 45. Jurnal Keuangan dan Perbankan.Vol. 14. No.2

Meidawati, Neni dan Harimawan, Mahendra. 2004. Pengaruh pemilihan umum legislatif Indonesia tahun 2004 terhadap return saham dan volume perdagangan saham LQ-45 di PT. Bursa Efek Jakarta (BEJ). SINERGI . Vol. 7. No. 1. ISSN : $1410-9018$

Mulatsih, Listiana Sri; Maskie, Ghozali dan Susanto, M. Harry. 2009. Analisis Reaksi Pasar Modal terhadap Pengumuman Right Issue di Bursa Efek Jakarta (BEJ) (Pengamatan terhadap Return, Abnormal Return, Security Return Variability dan Trading Volume Activity). Wacana. Vol. 12. No. 4. ISSN. 1411-0199

Putra, Ardian Prima. 2016. Analisis Investasi dan Manajemen Portofolio. Yogyakarta: Pustaka Pelajar

Saputra, Akhsani Lubis Dwi dan Darsono. 2015. Reaksi Pasar Atas Pengumuman Dividen Tunai (Studi Empiris Pada Perusahaan LQ-45). Diponegoro Journal Of Accounting. Vol. 4. No. 4. ISSN (Online): 23373806

Sari, Ni PutuTila Permata; Purnamawati, Gusti Ayu dan Herawati, Nyoma Trisna. 2017. Analisis Komparatif Saham LQ 45 Sebelum dan Sesudah Pilpres Amerika Serikat 2016. E-Journal S1 Ak Universitas Pendidikan Ganesha Jurusan Akuntansi Program S1. Vol. 7. No. 1

Satria, Rendi dan Supatmi. 2013. Reaksi Pasar Sebelum dan Sesudah Internet Financial Reporting. Jurnal Akuntansi dan Keuangan. Vol. 15. No. 2. ISSN 1411-0288 print / ISSN 2338-8137 online 